\title{
FOCUS
}

\section{AMNESTY AND PARDON IN ISLAMIC LAW WITH SPECIAL REFERENCE TO POST-CONFLICT JUSTICE**}

\author{
Mohammad Hashim Kamali*
}

\section{Introductory Remarks}

The subject before us has acquired renewed significance in the aftermath of the September 2001 terrorist attacks, the tumult and violence that has been on the increase ever since, but also what followed the advent of the Arab Spring in many Muslim countries. Conflicts that engulf countries and communities rarely, if ever, end by clean endings. They leave behind a host of issues, including the urge to take revenge by the aggrieved parties - hence a vicious circle of violence follows. Post-conflict justice requires careful management, such that measure- for -measure justice may not be the right option in one's quest to restore peace. The spirit of peace and willingness to give and take, admission of truth and forgiveness may be among the more effective means of healing and moving forward. What role, if any, is there in the midst of all this for Islam's guidelines on repentance, amnesty and forgiveness is the main subject I address in the following pages.

Amnesty, pardon and forgiveness are the means, in Islamic theology and law, as also in most other world traditions, of relieving someone from punishment, blame, civil liability or religious obligation. The same result is often achievable by recourse to certain other methods such as reconciliation, arbitration, and judicial order. This article focuses on an exposition of Islamic law provisions on amnesty ( $a f w a$ ). The fiqh positions explored here derive, for the most part, from the Qur'an (normative teaching), or Sunnah of the Prophet Muhammad, pbuh, and general consensus (ijma') of scholars across the generations. Yet instances are found where fiqhi interpretations of the relevant scripture are reminiscent of historical settings and conditions of their time, which may, upon reflection, warrant further scrutiny and interpretation more in tune with the contemporary conditions of Muslims. These have occasionally been explored in a quest for 
alternative answers. This approach is in line with the spirit of ijtihad that seeks the continuity of scriptural guidelines and their application to the changing conditions of society. A mere reproduction of scholastic positions is not always the best approach, not even recommended by the leading Imams and thought leaders of Islam.

Amnesty and pardon would be insignificant without the reality of an adverse consequence or punishment. For pardon without the ability to strike back is tantamount to helplessness. Yet reconciling pardon and punishment in the sphere of criminal justice, especially in a post-conflict setting, poses questions often of conflicting interests. At the theological level, the Qur'an clearly tells Muslims that God is both merciful and just, but how does the law meaningfully reconcile these two objectives. How can people act with mercy and forgiveness when a crime has been committed against them? These questions raise issues sometimes beyond legalities. Textual guidelines and fiqh rulings on justice, mercy, repentance and forgiveness are not always self-evident nor do they provide for facile combinations. Science and education, economic conditions and the culture of Muslim communities and entrenched tribal and customary practices also reflect on the fiqh positions. Phases of development and modernist culture accentuate fear of rampant mischief-making by individuals and groups that call for more rigorous approaches to legal interpretation. In a post conflict setting, the quest for healing and social harmony may sometimes need to look beyond legalities. Hence it is important to reflect on some of the broader teachings of the Qur'an and Sunnah, as well as principles, such as that of siyasah shar'iyyah (shari'ah-oriented policy henceforth called siyasah) that provide for a measure of flexibility and pragmatism.

Article Summary: I begin with a review of the meaning and scope of amnesty and proceed with an overview of the Qur'an and Sunnah on the subject. Then I explain the juristic relevance of amnesty to repentance, the prescribed penalties of hudud, and just retaliation (qisas) respectively. The basic purpose is to explore the permissibility or otherwise in Islamic law of amnesty in respect of the various types of criminals in these categories. Next I pose the same question and the likely responses that can be obtained from recourse to the principles of siyasah and ta 'zir (deterrent punishment) respectively. A brief comparison is then attempted between amnesty and reconciliation, which is followed, in turn, with a question: who grants a pardon and when - the crime victim, his relatives, or the head of state? The article ends with a section on the expiration of time (al-taqadum) and its impact on prosecution and punishment. 


\section{Meaning and Scope}

'Afwa literally means omission (isqat) or waiver and it is defined as exempting the wrongdoer by not taking him to account. Another Arabic synonym of 'afiwa is al-safh, which means to turn away from someone but also to widen the space and incline toward reconciliation. In this sense al-safh involves taking a step beyond 'afwa. Yet another synonym to 'afwa that occur in the Qur'an and hadith is maghfirah, which is granted by someone in position of superiority and power. The difference between 'afwa and maghfirah is that the former implies waiver of blame and shame without, however, any addition of virtuosity to the account of wrongdoer, whereas maghfirah does have that implication and can add spiritual reward to the wrongdoer's account. Both 'afwa and maghfirah require omission of punishment, but the latter can also add a reward. ${ }^{1}$ In fiqh terminology, 'afwa means a waiver of a duly warranted punishment for wrongdoing - this being the special meaning of 'afwa as 'afwa does not always lead to omission of punishment.'

The Arabic word 'afwa subsumes all of its three English equivalents: amnesty, pardon, and forgiveness. Pardon may be granted by an individual or a group of individuals, and by extension also by a corporate body or institution. ${ }^{3}$ I may employ amnesty and pardon when there is substantial involvement of government authorities, and forgiveness when the initiative belongs to an individual or a nonstate party, although pardon also stands good with reference to both.

\section{The Qur'an and Sunnah: An Overview}

'Afwa is a major theme of the Qur'an and takes a high profile in the Islamic order of values, being the subject of over thirty verses in the Holy Book that subsume legal, religious, moral and cultural dimensions. The Qur'an often speaks in praise of those who take a forgiving attitude toward people; 'afwa is designated as a manifestation of ihsan (beauty and goodness - Q al-Baqarah, 2:178). Then also God the Most High associates His illustrious self with forgiveness and speaks of His love and affection for those who forgive without vindictiveness, especially when they are overwhelmed with the urge for revenge (Q Aal-'Imran, 3; 134). Pardoning is especially meritorious by someone who can avenge but chooses to exonerate and forgive. Yet Islam also puts a high premium on justice that may well demand sternness, especially from a leader or judge, to bring the wrongdoer to account. Justice and amnesty often moderate and temper one another but can also conflict. To quote the Qur'an:

God commands justice ( $a l$-'adl) and the doing of good (al-ihsan) and generosity to one's kindred, and He forbids indecency, wrongdoing and oppression." (Q al-Nahl, 16:90) 
Justice in this verse is enjoined side by side with ihsan, and the juxtaposition implies that it is not always the measure for measure approach that is desired; justice should be tempered, whenever appropriate, by ihsan, which in this context subsumes amnesty. Punishing the wrongdoer is the normal course enjoined by the Shariah, but amnesty may be preferable at times. God thus praises:

Those who spend in the way of God, in times both of prosperity and hardship, and those who control their anger and forgive their fellow humans. Truly God loves the muhsinin (those who persist in ihsan)" (Q Aal-'Imran, 3:134).

Elsewhere the Qur'an speaks of proportionality and equivalence in punishment, but espouses it with a recommendation for forgiveness:

Whoever transgresses against you, your response should be proportionate to the transgression committed against you (Q al-Baqarah, 2:194).

And the recompense of an evil is an evil equal thereto, but he who forgives and seeks reconciliation, his reward shall be with God, and God does not love the wrongdoers (Q al-Shura, 42: 40).

Tribal Arabia was prone to violence especially in situations where consultation and arbitration (shura and tahkim respectively) failed to end conflict. Tribal justice was also prone to exaggeration in revenge, which is why the Qur'an took an emphatic stand on proportionality and equivalence that inclines toward forgiveness. The relevance of these guidelines can hardly be overestimated in the wake of sectarian and tribalist violence that has plagued Iraq and many other countries, including Lebanon, Libya, the Yemen and Mali. The Qur'anic verse just quoted is followed, two verses later, by what is even more meritorious than proportionality in revenge:

But (remember) one who endures with fortitude and forgives, that indeed is a most distinctive of all deeds - min 'azm al-umur (Q alShura, 42:43).

Reconciliation, amnesty and forgiveness in these passages fall under the Qur'anic principle of benevolence (ihsan), which are highly appraised and preferred, whenever appropriate, to exacting and punitive approaches, and even justice (' $a d l$ ). But if one chooses to strike back, it must be proportionate to the pain inflicted on one in the first place.

The Qur'an also commanded the Prophet to "hold to forgiveness, enjoin kindness, and turn away from the ignorant." (Q al-A'raf, 7:199). Amnesty and kindness thus go hand in hand and the one become indicative of the sincerity of 
the other. As for those who fall into error out of ignorance, one is best advised to turn a blind eye and not let oneself be provoked by their behaviour. The Prophet himself strongly appraised the virtue of forgiveness, as in the hadith: "forgiveness does not fail to bring honour to a servant of God when he grants it (for His sake)." "4 The Prophet also showed this on the occasion of the conquest of Makkah in the year 8 Hijrah: He declared general amnesty to all Makkans that included his former enemies and persons who had committed acts of atrocity and aggression against the Prophet and his family members.

'Afuww (most forgiving) is one of the Excellent Names of God as in the verse: "whether you do good openly or in secret, whether you pardon the misdeeds of those who wronged, God is Ever Forgiving, All-Powerful ('Afuwwan Qadira) (Q al-Nisa', 4:149).” Interestingly enough, God's pardoning is here juxtaposed with His unbounded ability and power. Pardoning is also a most distinctive of the virtues of Prophets and Messengers, and should therefore be emulated by everyone, especially in dealing with one's parents and family, and the wider community, whenever it is likely to put an end to conflicts. ${ }^{5}$

The Prophet Muhammad is frequently reported to have granted pardon to those who wronged him. Jabir bin 'Abd Allah has thus narrated that when a Jewish woman from Khaybar served the Prophet some poisoned mutton, he took a small amount, but some of his Companions took more and fell ill. When the Prophet questioned her later: "did you poison that meat? She said 'yes.' Some of the Companions present asked the Prophet 'would you not order that she be killed!' The Prophet replied in the negative, and granted her pardon. Here was a great leader showing the way, so graphically exhibited, as to how Islam values forgiveness by one who has the power to strike back. The next two incidents I recount are also striking. ${ }^{6}$

Jabir bin 'Abd Allah reported that on one occasion he fought a battle in the company of the Prophet and upon return the Prophet rested under the shade of tree and hung his sword, "and we all fell asleep. The Prophet then alerted us when he caught red-handed a Bedouin who had taken the Prophet's own sword and attempted to strike him, at which point the Prophet woke up and questioned the man, but then pardoned him and let him go."”

According to another report, on the authority of 'Abd Allah ibn Mas'ud, the Prophet was wounded by an enemy soldier in the Battle of Uhud and was wiping blood from his face while also uttering the words: "O my Lord! Forgive my people, for they do not know-" the very same prayer that was once uttered by the Prophet Noah. ${ }^{8}$ Similar other reports have been narrated by the Prophet's widow, 'A'ishah, to the effect that the Prophet often granted pardon to people who wronged him, and in addition would pray to God to guide them to the right path. ${ }^{9}$ 


\section{Amnesty and Repentance: the Hudud Crimes}

Repentance (tawbah) and amnesty are logically connected, as amnesty is usually due when the offender shows remorse and repents. Muslim jurists have thus discussed amnesty and repentance in the context of hudud penalties (note that hadd and its plural hudud are used for prescribed crimes and punishments both) and qisas (just retaliation). I shall begin with the hudud and address qisas separately below.

It will be noted that hudud consist of two main components, namely the Right of God (haqq Allah) and Right of Man (haqq al-adami), or a combination of the two. The legal consequences of amnesty vary according to the manner in which it relates respectively to infringement of the Right of Man, or private right, and the Right of God, or public right. Juristic views vary on which of the hudud crimes consist of each of these rights and in what proportions.

Amnesty is permissible, even recommended, in the case of exclusively private rights. When rights of this kind are violated, as in cases of personal debt and ownership rights, the right to just retaliation (qisas) and preemption (shuf'a), ${ }^{10}$ the right bearer may grant forgiveness at his discretion, and is in some cases encouraged to consider granting it.

Hudud are held to be fixed and mandatory penalties that consist of public rights violations wherein amnesty plays a minimal role if at all. Neither the individuals nor the authorities are vested with powers to grant amnesty over the hudud crimes, especially after the offence in question has been duly reported to the authorities. The victim of hudud, if still alive, and his or her guardian (wali) in the event of the victim's death, have no recognised right to grant amnesty. ${ }^{11}$ Government authorities cannot be selective in the enforcement of hudud either: to enforce them in some cases and omit them in others. The government has a duty to enforce the hudud, just as is the case with the administration of justice, and enforcement of people's rights. It is an act of merit and sacred service ('ibadah) for everyone to facilitate the same, just as is the case with giving testimony in the cause of justice. Government leaders are themselves liable to hudud without any prerogative or discrimination - if they commit the offence. A reference is made in this connection to the Prophet's renowned Farewell Speech (hajjat al-wida), and instances even before then, wherein he asked the people if he had punished, verbally abused or hurt anyone, or taken anyone's property, they may retaliate and claim what is due to them.

There are differences of detail among jurists as to whether all or only some of the six or so hudud crimes belong to the Right of God category. They have disagreed, for instance, over slanderous accusation (qadhf), being one of the hudud offences, as to whether this actually belongs to the private or the public 
rights category. The majority of jurists have considered qadhf to combine both, but they differ again as to which constitutes the greater part. The majority seem to have considered qadhf to consist predominantly of a private right, and consequently entitle the victim of this offence to pardoning the offender.

An issue arising is whether repentance does in any way impact the question of punishment, and whether it begets amnesty and if so under what circumstances. With the exception of the Hanafis who hold that amnesty may not be granted on any ground in the hudud offences of adultery, intoxication, and theft (thus leaving out wine drinking, slanderous accusation and apostasy) - the other schools have held different views even on the latter three offences. There is consensus, on the other hand, on the permissibility of both repentance and amnesty in hudud before they are reported to the authorities and the offender has shown remorse. This position extends to a thief who repents and returns the property to its owner before it is reported to the authorities. On this even the Hanafis agree that repentance may beget amnesty as there would basically be no case to warrant prosecution and punishment.

The issue of repentance in two of the hudud crimes, namely apostasy (riddah) and highway robbery (hirabah) is especially debated. With regard to hirabah, if it does not involve loss of life and property and the offender surrenders himself to the authorities prior to subjugation and arrest, amnesty is permissible by the clear text of the Qur'an (Q al-Ma'idah, 5: 34). This long verse assigns specific penalties ranging from crucifixion, mutilation of limbs, and exile for convicted criminals depending on the involvement or otherwise of terrorism, loss of life and property - the text then provides: "except for those who repent prior to subjugation. Know that God is Forgiving, Most Merciful." The text not only permits repentance in what is evidently the most severe of punishments for any crime available in the Qur'an, but also refers to God's unbounded mercy and forgiveness. Then it is argued: if God the Most High opens the door to repentance and amnesty in this case, one may extend the spirit of this flexibility, as Abu Zahrah (d. 1974) has observed, to all the other hudud offences. Added to this analysis is the case of Ma'iz bin Malik, who came to the Prophet and made a confession of his act of zina and requested to be punished - notwithstanding the Prophet's repeated intimations that Ma'iz may have erred and may want to withdraw his confession, Ma'iz repeated his confession and was consequently stoned to death. But when this was reported back to the Prophet, he asked: "did they not let him go- ala taraktumuhu," as he had sincerely repented. This is also in line with the overall juristic position on the issue: when the thieves or wine drinkers confess and repent prior to punishment, they may be granted amnesty in so far as the Right of God/ public right aspect of the offence is concerned, but they are still accountable for violation of the private right therein. The question as to whether repentance is 
genuine is normally ascertained in the case of theft when the thief returns the stolen goods to its owner, and also if the drunken person amends any harm he might have inflicted on someone's person or property. As for a Muslim who renounces Islam, then repents and embraces the faith again, he is also to be exonerated. ${ }^{12}$

There is disagreement, however, with regard to inchoate crimes. Muslim jurists have recorded three different views as to whether repentance prior to completion in hudud offences is admissible and whether amnesty may be granted on its basis:

1. Some Shafi'i and Hanbali jurists have referred to the Qur'anic text on highway robbery which clearly admits repentance prior to subjugation, adding further that explicit references to repentance are also found in Qur'anic verses on theft and adultery respectively (i.e. Q 5:39 \& 4:16). On a broader note, they have held that repentance suspends punishment prior to arrest and prosecution in those of the hudud crimes which consist predominantly of public right/ haqq Allah, such as adultery and wine drinking, but not in crimes such as qisas, battery and bodily injury which belong for the most part to the private rights category. It is further stated that the sincerity of repentance must be proven by corrective action and a clean record of avoidance. This last would, in turn, require a waiting period, which is why some jurists have viewed it as a delaying factor that cannot be known at the material time - hence recommending its omission. ${ }^{13}$

2. Imams Malik (d. $795 \mathrm{CE}$ ), Abu Hanifah (d. $767 \mathrm{CE}$ ) and some jurists in the Shafi'i and Hanbali schools, maintain that repentance does not exonerate the offender from hudud punishments, except in the case of the highway robbery by virtue of a clear text. With regard to the hadd of adultery, it is added that notwithstanding Ma'iz bin Malik's confession, the Prophet, pbuh, still authorised execution of punishment. Hence the highway robbery is to be treated as sui generis, and not made the basis of any analogy. That the Qur'anic verses on adultery and theft too impose punishments in general and unqualified terms, whether the offender repents or not -hence they are all liable to the same punishments regardless of repentance. The proponents of this view have further questioned the analogy between hirabah and other hudud crimes saying that the Qur'an made an exception for perpetrators of this crime as they are usually terrorists whose arrest and subjugation may be difficult, but that this is not the case in other hudud offences. Moreover, suspending punishment because of repentance is likely to interfere with the rule of law and entice criminals to baseless repentance. In conclusion, the offender's repentance prior to completion of crime is neither a basis for pardoning nor for suspension of punishment. ${ }^{14}$ 
3. Ibn Taymiyyah (d. 1327 CE) and his prominent disciple, Ibn Qayyim alJawziyyah, of the Hanbali school have held: just as punishment cleanses the transgressor, so does repentance prior to completion of his crime. The public rights aspect of the offence in question is accordingly open to amnesty by the authorities, but not the part that pertains to private rights. ${ }^{15}$

The general position in modern law is that repentance by the offender does not exonerate him from punishment, except for some countries such as Egypt and France, which exonerate the criminal that abandons the crime before completion. This is in line with the view taken by some Muslim jurists as reviewed above. In common law jurisdictions, including Britain and India, an inchoate crime does not necessarily invoke amnesty. ${ }^{16}$

Abu Zahrah has discussed the various views on the admissibility or otherwise of repentance and grant of amnesty on its basis and wrote that there are clearly differences of opinion. In response to a question whether repentance even after arrest and adjudication can be the basis of amnesty, Abu Zahrah says that some of the views are based on questionable interpretations, especially over what the Prophet, pbuh, has said concerning the case of Ma'iz. That some of "their own reasoning point to the credibility of repentance even after adjudication, and even at the point of enforcement. The truth is that the Prophet has considered this (i.e. repentance prior to enforcement) as a revocation of confession (ruju' fi'liqrar)." ${ }^{17}$ He then quotes Abu'l-Hasan al-Mawardi (d.450/1058), a Shafi'i jurist and author of Kitab al-Ahkam al-Sultaniyyah, who wrote that repentance is only admissible prior to arrest and adjudication. Then he quotes the Hanbali scholar and contemporary of al-Mawardi, Abu Ya'la al-Farra, who wrote in turn:

If the adulterer repents prior to subjugation, the hadd punishment is to be suspended, and this is the case also regarding the thief and highway robber/terrorist, both of whose cases are so mandated in the text of the Qur'an. Abi'l-Harith thus narrated from (Imam) Ibn Hanbal (d. 869 $\mathrm{CE}$ ) that when the thief repents prior to subjugation, the punishment of mutilation is suspended. Al-Maymuni has also narrated from Ibn Hanbal on two separate occasions concerning the adulterer, concerning whom he (Ibn Hanbal) said on one occasion: when he confesses four times before the hadd is enforced, his repentance is admitted and the hadd is consequently suspended. Maymuni added that he spoke to Ibn Hanbal in another meeting and he said: if he revokes his earlier confession, the stoning punishment is suspended. ${ }^{18}$

This view can hardly be ignored, notwithstanding the majority position that does not allow space for repentance and amnesty in zina. A holistic reading of the text clearly rises above many of these juristic stipulations. To quote the Qur'an on adultery: 
As for the adulterer, man and woman, flog each of them a hundred lashes, and let not compassion move you away from carrying God's law, if you believe in God and the last day ... and those who accuse chaste women and fail to produce four witnesses, flog them eighty lashes and do not accept their testimony ever after, for they indeed are evildoers (fasiqun). Except for those who repent thereafter and reform themselves (illal-ladhina tabu min ba'di dhalika wa aslahu). Then God is Forgiving, Most Merciful. (Q al-Nur, 24: 2-6)

Some commentators have raised questions about the precise implications in this verse of the pronoun al-ladhina (except for those) whether the reference is to slanderous accusers, or to evildoers (fasiqun) in general, and whether the adulterer can also be included among those who may be allowed to repent. Whatever the nature of that debate may be, it would appear that fasiqun only describes the preceding offenders and does not introduce a new, independent and rather ambiguous category as such. I now quote the verse of theft:

As for the thief, male or female, cut off their hands as retribution for their deed, and punishment from God as a deterrent. And (remember) God is Most Mighty, Most Wise. But whoever repents after his crime and mends his ways (fa-man taba min ba'd-e zulmihi was aslaha), God pardons him. For God is Forgiving, Most Merciful. (Q al-Ma'idah, 5:38-39)

The uninterrupted sequence of this verse is self-evident, there being no other subject in between: theft, its punishment, God's Power, repentance, pardon, God's Pardon and Mercy.

Based on the general principle, in both the Islamic and modern law, that criminal legislation should be interpreted in favour of the accused and on the side of leniency, it is submitted that all of the preceding categories of offenders are included in God's mercy and pardon and thus afforded the opportunity, on a selective basis at least, to repent and reform themselves. For otherwise the repeated Qur'anic emphasis on this theme would have been relegated to moral teaching. The hudud are clearly not treated as moral precepts alone. In sum, the verses under review explicitly extend the prospects of repentance and pardon to four of the hudud offences: adultery, slanderous accusation, theft - as well as highway robbery. On the subject of adultery, elsewhere the Qur'an again provides:

If the two of them are guilty of lewdness, punish them both. If they repent and correct themselves (fa-in tabaa wa aslahaa), leave them alone (fa'ridu 'anhuma). For Allah is oft-Returning, Most Merciful (Q al-Nisa': 4:15-16). 
Unlike the somewhat obscure view that this verse has been abrogated, Abu Zahrah refutes the suggestion, saying that the text before us is perspicuous (muhkam) and it is not, as such, amenable to abrogation in the first place. ${ }^{19}$

Abu Zahrah's analysis is sound. Even though he falls short of taking some of his points to their logical conclusions, he has given sufficient indication that repentance and pardon need not be put under too many restrictions, simply because the Qur'an and Sunnah do not sustain them.

Tawbah (repentance, atonement and self-correction) is a major theme of the Qur'an occurring in over 120 places in the Holy Book, and much emphasis on it is also found in the Sunnah, which are undoubtedly reflective of Islam's essence of forgiveness, without compromising on the rule of law aspect of combating lawlessness and crime. Only with regard to terrorists and highway bandits is there a limitation in the text as already reviewed. The wider implications of that verse regarding other hudud penalties have also been seen in two different ways, one in favour of repentance and amnesty, even after subjugation and arrest, and the other against. As already mentioned, textual interpretation on penalties should be on the side of leniency whenever the text can accommodate such, as is indicated in the following hadith:

'A'ishah reported that the Prophet, pbuh, said: "suspend the punishments whenever there is doubt (idra'u al-hududa bi'l-shubhatnote that hudud at that time was used in reference to all punishments, not to hudud alone as this expression acquired a technical meaning much later) and find a way out of them for Muslims whenever you can. If the Imam errs, it is better that he errs on the side of amnesty rather than punishment. ${ }^{20}$

The present writer has elsewhere discussed repentance in the Qur'an with a view to integrating it into the theory of hudud in a wider study. I have advanced the view that when reformation and repentance are so integrated, then one must depart from the notion that hudud are fixed and mandatory penalties over which the judge, the head of state and mujtahid have no role other than enforcing them upon proof. For juristic stricture that characterises the hudud discourse in fiqh has made the hudud difficult to implement, in the past as also in our own time. Due to severity of some of the punishments involved, judges and prosecutors are generally reluctant to enforce them. But improvement is possible if one were to open the hudud to reasonable levels of interpretation and ijtihad that can be sustained by the textual evidence. ${ }^{21} \mathrm{I}$ have discussed this elsewhere and referred in this connection to a letter that Abu Yusuf (d. 182/798), the then chief justice, wrote to the Abbasid caliph, Harun al-Rashid, in such terms as "if you would order that the hudud should be enforced (fully) it would help reducing the prison 
population, frighten the transgressors and prevent crime." 22 The letter indicates that judges had problem with the enforcement of hudud even at that time.

Some of the figh positions are also debatable. For instance, Abu Zahrah has found inconsistency in Imam Shafi'i's (d. $820 \mathrm{CE}$ ) reported rulings, as different versions, some affirmative and some negative, have been recorded by the Shafi' $i$ school. Having looked into them, he writes: "we are inclined to conclude that the affirmative view (on admissibility of repentance) is the preferred position of Imam Shafi 'i." ${ }^{\prime 23}$ That this is the correct position of the Shafi' $i$, Hanbali and other schools of figh is further supported by the hadith: "One who repents from a $\sin$ is like the one who has committed none." ${ }^{24}$ It follows therefore that sincere repentance in some crimes at least, removes the stain and the person is no longer guilty, hence not liable to punishment either. ${ }^{25}$ Added to this are the Qur'anic verses on theft, slander, adultery and hirabah, which are explicit on the admissibility of repentance.

As for apostasy, there is a minority opinion that it is not a hadd but a ta zir offence. ${ }^{26}$ The majority considers apostasy to be a hadd, yet they permit repentance after the sentence has been passed but before execution. The offender may repent during this interval, and if so, amnesty may be granted by the authorities.

Textbook writers are almost unanimous on the following three conditions a valid repentance must qualify: 1) it must be indicative of remorse over what has happened; 2) it must be expressive of determination not to repeat the conduct in question; and 3) that there is no actual recurrence. Yet it is added that the first two are mental conditions that are hard to prove by evidence. All that one can do is to scrutinise the veracity of the statement the accused person makes before the court. As for the third condition, this too is difficult to ascertain as it involves future projection. There is general agreement, however, that hadd punishment is suspended concerning an offender who sets a clean record, after a duly recorded repentance "for a long period of time." Imam Abu Hanifah and his disciples have held that expiry of a long time suspends the hadd punishment, whether before or after reporting, and even regardless of repentance. The other schools stipulate, however, that repentance suspends the hadd only before the offence is reported to the authorities, and some have said even after that, and that repentance is valid if followed by a long clean period. "A judicial repentance - al-tawbah al-qada'iyyah - verifies the truth of repentance upon expiry of six months, some just mention 'a long time' in which the person concerned stays clear of repetition." ${ }^{27}$ With regard to the thief, a good sign of the truth of his repentance is the return of stolen goods to its owner prior to arrest and prosecution. 


\section{Siyasah and Ta'zir}

Islamic criminal justice is only partially regulated by the clear text, which obtains mainly with regard to hudud crimes and qisas, but the much larger area of crimes and penalties has been, through much of the Islamic history, regulated by state laws and ordinances that broadly fell under the rubric of Shariah-oriented policy, or siyasah, which subsumed, in turn, the deterrent yet unquantified punishment of ta 'zir. Measures introduced by way of siyasah must address issues and problems as they arise in a way, however, that combine various influences, including the higher purposes of Shariah (maqasid al-shariah). ${ }^{28}$ Questions also arise as to the philosophical viewpoint and attitude taken toward punishment, including retaliation, reform, and the possibility also of amnesty to individuals and groups, especially in the context of post-conflict justice. Whether a legal punishment is to be carried out against a repentant, first time offender, and a non-repentant recidivist alike, and how should one be bound by issues of legality while facing the larger concerns of peace and normal order in a fragile environment such as now prevails in Afghanistan, Iraq, and many other places - underscore the importance of the Islamic public law principle of siyasah. For siyasah empowers the authorities to act in accordance with the spirit and objectives of Shariah at the expense even of a certain departure from scholastic interpretations and ijtihad. ${ }^{29}$

Note the concern also over the hudud, as one observer put it, that they "are nowhere fully enforced in the Muslim world. This fact demonstrates that an update of the criminal justice system in Islam is one of the major challenges that need to be taken up by Muslim opinion leaders and governments. ${ }^{30} \mathrm{Hudud}$ lie at the core of the Islamic criminal justice and cannot as such be marginalised, yet judicial practice is varied over them such that they are by and large replaced by other punishments, especially imprisonment, which may be seen as instances generally of $\mathrm{ta}^{\prime} \mathrm{zir}^{31}{ }^{31}$ There has been renewed interest in recent decades over the implementation of hudud laws in some Muslim countries, such as the Islamic Republics of Pakistan and Iran, the Sudan, Nigeria and elsewhere, but the practice of hudud is on the whole partial and inconsistent. The state authorities in most of the Muslim countries tend to shy away from regulating the hudud in a systematic way that could address issued faced by the judges and prosecutors. Other factors in this picture are the contemporary human rights discourse and Western opinion that have taken issue with the hudud penalties. One may add to this analysis an evolving trend since the tumultuous events of September 2001 and that now gives the hudud a different dimension, namely the unprecedented increase of terrorism and violence, suicide bombing, drone attacks and state terrorism. Post conflict justice does not escape the suspicion that war lords and criminals take high positions and become influential in government. The state itself is sometimes 
seen as complicit to crime - hence a fresh demand for the restoration of hudud laws that are known to be more resolute and less dependent on the vicissitudes of politics and divergent demands of questionable interest groups.

$\mathrm{Ta}$ 'zir is basically an open-ended category that extends to almost all other punishments outside the hudud and qisas wherein the judge and head of state may exercise discretion in determining a deterrent punishment for an offence in light of the circumstances surrounding the case and conditions of the offenderor else to grant amnesty if they deem it to be the best course of action. There is general consensus on this, but disagreement is recorded as to whether such discretionary powers exist with regard to all ta'zir offences. Thus it is said that when a hadd punishment is reduced to ta zir due to some deficiency in its proof or other material aspects of the offence - it would be exceptional and the authorities may not grant amnesty over it. ${ }^{32}$ As already noted, ta 'zir is a subtheme of siyasah, which vests the authorities with discretion in punishments and court procedures. But even in ta zir, it may be added that the judge does not create the offence but only a suitable punishment for a behaviour type which is held to be a transgression ( $m a$ 'siyah), or denounced in some way in the Qur'an, Sunnah and general consensus. ${ }^{33}$

\section{Amnesty in Qisas (Just Retaliation)}

Literally qisas means equivalence, implying that a person who has committed murder, manslaughter or bodily injury, will be punished in the same way, in the same proportion and by the same means as he employed in killing or injuring his victim. Ascertaining this degree of equivalence and proportionality is not always possible, such as in the case of a broken bone, in which case a suitable substitute is to be applied. If the offender is a minor or insane, there shall be no qisas but only the payment of blood money (diyyah), which according to the majority, is payable by the family of the offender. An exception to the rules of equivalence is also made for the father: If the father kills his son, he is not liable to retaliation but a deterrent punishment (ta 'zir) only. As a general rule, the death of the offender himself removes all claims, and all proceedings shall cease, except for any loss of property, or outstanding debts, which are normally inherited by the heirs of the offender. ${ }^{34}$

Qisas must be carried out in the least painful manner. Equivalence naturally means that a person may not inflict a harm greater than was inflicted on him. Qisas is the principal punishment for murder, whereas payment of blood money $(\text { diyyah })^{35}$ is the principal punishment of unintentional killing and culpable homicide. Diyyah may also be payable in murder cases in which the relatives of the victim pardon the killer from execution and choose to receive a compensation. 
Diyyah is payable by the criminal himself, or by his agnatic relatives. ${ }^{36}$ Muslim jurists are in agreement over the permissibility of amnesty in qisas based on the following Qur'anic address to the believers:

Retaliation is prescribed for you in all cases of murder, but if remission/ pardon is made to one by his (aggrieved) brother, prosecution (for blood money) should be according to usage and payment in fairness. This is an alleviation and mercy from your Lord. But anyone who resorts to aggression after that shall bring upon himself a painful punishment $(\mathrm{Q}$ al-Baqarah, 2: 178-179).

Pardoning by the next of kin in qisas cases may seem eminently suitable in certain family conflicts: in a case, for instance, where retribution can only add to the agony of the next of kin who is also the surviving relative. Supposing a man is slayed by his own brother, and the father, who is entitled to ask for qisas, now finds himself in a sorry predicament of having to lose his only other surviving son. Then it would seem that pardoning offers a preferable course. A case also arose of a murder during the time of the caliph 'Umar al-Khattab wherein the deceased person's relatives requested qisas. Then came the wife of the murderer who was also the deceased person's sister and entitled to grant a pardon. She voluntarily declared that she wished to pardon the killer, and the caliph saved the murderer from execution as a result. The woman found herself in a situation of having lost her brother and then about to lose her husband as well. ${ }^{37}$

The law of qisas is premised on total equality, and thus applies in all cases of murder regardless as to whether the victim is a child, insane, elderly or ill, male or female. The principle of life for life is the essence of equality in qisas law. Qisas has two components that involve public and private rights, of which the latter is predominant, as it is the right of the family and close relatives of the victim and only they are entitled to grant a pardon over it. ${ }^{38}$ But even when the crime victim or his next of kin grant a pardon, the public right aspect of qisas, be it in homicide or bodily injuries still remains and it is for the public authority to grant it if the public interest so dictates. The head of state, judge, and public prosecutor/ attorney general have no powers to grant amnesty over a private right in qisas itself or its monetary substitute, the diyyah. Even when the victim or his relatives grant a pardon, it does not in any way derogate from the government's power of amnesty or prosecution over the public right aspect of qisas, which has obvious implications for peace and public order, and the punishment so imposed partakes in ta 'zir. There is disagreement on the maximum limits of a ta zir punishment. Whereas the Hanafi and Shafi'i schools maintain that it should not in any category exceed the hadd punishment, the Maliki and Hanbali schools maintain, on the other hand, that $t a$ 'zir may, in exceptional cases, include death punishment. ${ }^{39}$ 
The crime victim or his family's right to pardoning is thus limited to punishment, but not to crime as such. In the event even when the victim or his relative specifically pardon crime and punishment both, it would only relate to the punishment but not the crime. For had the right-bearer of private right the authority to exonerate the offender from both the punishment and crime, there will remain nothing for further intervention by head of state or Attorney General in respect of imposing a punishment on account of the public right violation of the offence. ${ }^{40}$ Applying the qisas law is problematic under modern law wherein the government itself, or its Attorney General, represents the public rights aspect of the offences. Modern criminal law is generally not in tune with the fiqh division of rights into the binary categories of Right of God and Right of Man ( $h a q q$ Allah, and haqq al-c $a b d$ ). Departures from the fiqh provisions to a different regime of laws began with emergence of the modern nation state. Whereas the said division was premised on the prominent role of tribe and family in criminal justice, that role was no longer recognised in a system of criminal law that had departed from the fiqh premises. The family unit, especially the agnatic relatives were previously responsible for payment of diyyah in the event of pardoning or reconciliation. Some of those roles also became exposed to new questions in view of the availability, under modern law, of pension rights, life insurance plans and so forth.

Fiqh scholars of all madhhabs have spoken on the virtues of 'afwa as an act of great merit simply because the Qur'an declares it so: "But he who grants a pardon, it shall be an expiation (kaffarah) for him." (Q al-Ma'idah, 5:45, see also Q al-Baqarah, 2:178 as reviewed above). ${ }^{41}$ In a similar vein, the Prophet's Companions, Anas bin Malik, has reported the following: "No case of qisas came before the Prophet, pbuh, wherein he did not advise the grant of pardon." ${ }^{" 42}$ What it means is that the Prophet was strongly inclined towards pardoning in qisas, but not always, especially when the enormity of crime dictated a firm response. Given in illustration for this was the renowned case of a Jew who had killed his female slave by placing her head between two rocks and crushed it. When the case came to the Prophet, the heinousness of that killing convinced him that pardoning would only mean condoning cruelty. The man was thus executed in line with the spirit of the Qur'anic dictum: "and there is life for you in qisas, O people of understanding - so that you can protect yourselves against aggression."( $\mathrm{Q}$ alBaqarah, 2:179). ${ }^{43}$

Pardoning in qisas can promote a good cause when the killer acts in haste and anger and then shows remorse. Ibn Taymiyyah has thus observed that the Qur'an designates pardoning as a form of ihsan (beauty and goodness- as in $2: 178)$ provided that no one is harmed by it, but if harm were to arise from pardoning, then it is unlawful. ${ }^{44}$ The Maliki school has upheld the permissibility 
of pardon except in the case of al-ghilah, which is to slay for the sake of taking the victim's wealth. For this would partake in terrorism/hirabah, and when the terrorist/muharib kills in that way, he must be executed and no room for pardoning remains. The terrorist is killed in this case, not by way of qisas, but as a prescribed hadd crime wherein the authorities have no choice but to protect the community against crime and corruption ( fasad fi'l-ard).

When a pardon is duly granted, all hostility must cease. This is the clear ruling of the following hadith:

One who is victim of death or injury has one of the three options, and if he opts for a fourth, he must be grabbed by the hand (and stopped): to retaliate, or forgive, or take blood money. One who does other than these indulges in excess and will suffer the torment of Hell forever. ${ }^{45}$

The main message of this hadith is on cessation of hostility: when solution to a conflict has been found and agreed upon, whether through pardoning, financial compensation or punishment, from that point onwards, all hostility must cease. This is relevant to post-conflict justice in that all parties concerned in homicide and crimes of violence should try to reach a settlement and then cease all hostility as of that time. The Shariah provision on blood money or diyyah can also be gainfully applied as a means of settlement in post-conflict situations. This may be an agreed upon sum, or one that is now specified in some laws, such as in Pakistan, or by reference to life insurance practices. Barring exceptional cases where murder charges or crime against humanity can be successfully proven, most other instances of homicide are likely, in post-conflict situations, to be faced with difficulties of evidence and proof due to passage of time and involvement of a host of other factors. Attempts at reconciliation and negotiated settlements are more likely to boil down to a reduced charge of manslaughter, which can be settled on the basis either of compensation by way of diyyah, or amnesty based on admission of truth and repentance, whichever is deemed preferable under the circumstances.

\section{Pardon and Reconciliation ('Afwa and Sulh) Distinguished}

When the private right-bearer grants pardon in qisas, it is regarded as 'afiwa proper if he grants it without a consideration, but if he only waives his right to retaliation in favour of taking blood money, then it is arguably not a pardon, but a case of reconciliation (sulh). This is the view of Imams Malik and Abu Hanifah. The explanation is that the giving or taking of diyyah must be agreed by both parties, including the offender, and that turns it into an exercise in sulh. The effect is about the same as both pardon and reconciliation suspend qisas and certain other punishments too. Just as a pardon may be granted in qisas, it can also be in 
granted respect of diyyah, regardless as to whether the diyyah in question is the primary punishment, as in manslaughter, or a substitute punishment that replaces the primary punishment, namely of qisas in murder. ${ }^{46}$ Reconciliation in qisas is also valid for monetary compensation with or without a reference to diyyah, and for any amount based on agreement of the concerned parties. It may be for cash or kind, be it of the same kind as diyyah or otherwise, and whether prompt or deferred for a specified period - all variations are acceptable. For the next of kin has a right and is therefore entitled to waive it gratis or in exchange for compensation.

Whether it is qisas or diyyah or sulh, they do not take effect automatically but need to be proven beyond doubt in the court of justice and authorised by a valid judicial order. The manner in which qisas is carried is also subject to supervision of the relevant authorities, not by the individuals concerned, as there will be fear of excess and the Qur'an clearly enjoins moderation and equivalence. The relatives are thus given the power (sultan) to choose qisas but required in the meantime to: "Avoid going to excess (in retaliation) - Q al-Isra', 17:33."

The authority for sulh is provided in hadith as well as general consensus (ijma'). Text book writers quote the following hadith:

One who intentionally slays another should be handed over to the next of kin of the deceased, who may decide to retaliate if they wish, or take a diyyah, or attempt reconciliation (sulh) and the compensation they take also belong to them. ${ }^{47}$

The only restriction regarding the amount that may be agreed upon in sulh is when the legal heirs include minor persons, in which case the agreed upon sum should not be less that the amount payable in diyyah. However, if reconciliation is reached over the amount of diyyah, not over qisas as such, then the amount should not exceed the maximum that is payable in diyyah. For this would be a case of unwarranted increase and considered as riba (usury), which is unlawful. ${ }^{48}$ In juristic terms, sulh is a contract, which must fulfill three conditions: 1) that the agreed sum is clearly quantified such that precludes ambiguity and ignorance; 2) that it precludes non-halal substances such as alcohol; and 3) that it is not in respect of something that cannot be waived or alienated, such as someone else's share in inheritance. ${ }^{49}$

Reconciliation is encouraged as a method of conflict resolution among people, not only in respect of qisas and diyyah but in most other instances of conflict. The Qur' an thus describes reconciliation that brings peace as a better option generally (was-sulhu khayr - Q al-Nisa', 4:128); and provides in another place: "Truly the believers are brethren, so bring peace between your brothers - $Q$ al-Hujurat, 49:10; see also al-Anfal, 8:1" ${ }^{50}$ Reconciliation and compromise that facilitate peace and 
removal of conflict is a Qur'anic principle that the fiqh texts have elaborated under arbitration (tahkim), and reconciliation and negotiated agreement (sulh), with or without supervision of the regular judiciary. These may also be attempted within or beyond the existing law of the land. For peace is not always a question of legalities and conformity to normal procedure, although these do often merit consideration. It is a question often of inspiring the human spirit to rise above counting and measuring, to the level of ihsan, magnanimity and forgiveness for a noble cause, which is peace, and saving of lives through putting an end to conflict, which could otherwise continue to cripple the lives of individuals and communities. It becomes an urgent calling of all peace-loving people, Muslims and non-Muslims alike, to support the cause of peace and facilitate its realisation through all legitimate means at their disposal.

\section{Who Has the Right to Grant Pardon?}

Should there be only one surviving heir to the deceased person, then the theory of qisas entitles him or her to exercise the rights both to retribution and pardoning. But when the deceased is survived by several relatives all of whom are adults, pardon can still be granted by them collectively. Issues arise, however, when some of them pardon and others do not and insist on qisas. In response to this, the Imams Abu Hanifah, Shafi'i and Ibn Hanbal have held that pardon even by some of the heirs suspends qisas, for a requirement of qisas is that it is demanded by all the surviving heirs without exception. When some of them pardon, this by itself introduces an element of shubha (doubt) and qisas, like the hudud, collapses in all cases of doubt- also because the Qur'an and Sunnah encourage amnesty and forgiveness, as in the verse: "And the recompense of an evil is an evil the like thereof, but one who forgives and reconciles, his reward is with God." (Q alShura, 42:40, see also Q al-Nahl, 16:126)

There are two variant reports on Imam Malik's position, one of which is that pardoning, like qisas, must be granted by all the surviving heirs, and that the pardon of some is not enough to suspend qisas. The other view is more detailed and draws a distinction between male agnatic relatives and others and weakens itself by the discriminatory treatment of some over others. ${ }^{51}$ An issue also arises if some of the heirs are minor persons, then a question arises as to who is entitled to grant a pardon. Different views are recorded, some advise waiting until they attain majority, while others entitle their elder relatives/ guardians to represent them in pardoning. Another issue is also when some among the adult relatives are absent without known whereabouts - should one then wait for them all to be present. The preferred position does not advise delay and validates representation. ${ }^{52}$ 
In the case of bodily injury and loss of limbs, the right to pardon belongs to the victim of the crime himself, and there is general consensus over this. This is also the position in murder cases wherein the deceased person himself grants a pardon before he actually dies. The pardon is held to be valid, notwithstanding differences of opinion among jurists over details as to whether the pardon was for an injury or murder, the time interval, if any, the cause and effect sequence and so forth. ${ }^{53}$

The Shariah-ordained right of forgiveness by the victim or his relatives has a meaningful role in bringing conflicts to an end, especially in post-conflict situations. For it is the family and relatives of the deceased person who would most likely be pursuing the case. For the family to be vested with the right of pardon enhances their ability and standing in reconciliation efforts. When the purpose is to find ways to heal open wounds through forgiveness, benevolence and ihsan, recourse to the right of pardon add value to reconciliation efforts. This can be said perhaps with regard to post-conflict situations currently obtaining in Afghanistan, Iraq, Libya and Somalia where family involvement in reconciliation efforts can hardly be overestimated.

\section{Expiry of Time (al-Taqadum, also Murur al-Zaman)}

The issue before us is whether the right to reconciliation and grant of pardon, be it by the individual or government, expires, if at all, after a lapse of time in which no action is taken by any of the parties concerned. For lack of action over a long period is not only considered to introduce an element of doubt, but also affect reliability or otherwise of witnesses and other means of proof. Muslim jurists have recorded three different opinions on this:

The majority of Maliki, Shafi' $i$ and Hanbali jurists as well as the Zahiri and certain other early scholars maintain that the hudud and qisas, like all other rights, are not suspended by the passage of time. That neither the crime nor its punishment in hudud and qisas are liable to expiration however long the time may be, and due judicial process may be activated any time, although some jurists have held that the punishment of shurb (wine drinking) expires with time. The majority holds a different view, however, with regard to ta 'zir offences, which are subject to discretion of the authorities who may decide not to prosecute if they deem this to be in the public interest (maslahah 'ammah). For the head of state/ Attorney General has powers in this area to grant amnesty with regard to either the punishment or crime or both, and this can be any time.

The second view is that of the Hanafi school, which concurs with the foregoing in regards to qisas and diyyah, slanderous accusation (qadhf) and theft, which are not liable to expiration. But the Hanafis hold that the remaining hudud 
offences collapse and expire with the passage of time. They also hold that ta 'zir punishments are all suspendable and may be dropped on grounds of taqadum, regardless of their type and means of proof, but that hudud offences other than qadhf are also suspendable if their proof consist of witnesses, but not if it is confession, except for the punishment of shurb. ${ }^{54}$

The third view is attributed to an early jurist, Ibn Abi Layla (d. $768 \mathrm{CE}$ ), who held that taqadum suspends punishments generally. Hence neither testimony nor confession is admissible regarding old crimes. ${ }^{55}$

There is, however, some ambiguity as to the length of time for taqadum. One view in the Hanafi school holds that it is up to the judicial authorities to determine it in light of relevant factors, as a fixed time is difficult to determine such that can suitably apply to all excuses and delaying factors. Muhammad ibn Hasan al-Shaybani (d. $813 \mathrm{CE}$ ) has, however, held it at six months, whereas a report attributed to Imam Abu Hanifah and his other disciple Abu Yusuf (d. 798 CE) held it to be one month. ${ }^{56}$

Having discussed the various views, 'Abd al-Qadir 'Awdah (d. 1954) draws the conclusion that the head of state is within his rights to determine time limits for acceptance or otherwise of the testimony of witnesses if this be the sole means of proof for the offence. ${ }^{57}$ One may refer here briefly also to developments under Ottoman law on the subject of taqadum concerning three types of offences, namely of felony, misdemeanor, and violation respectively. A felony expires after ten years, a misdemeanor after three, and a violation after one year. ${ }^{58}$ These time limits have also been upheld in some follow- up legislations in the Middle East and Asia. They seem generally sound, and often necessary to curb doubtful claims that prolong conflicts among people. Felony would subsume the hudud and qisas, whereas ta 'zir may broadly fall under the other two classes of offences.

Taqadum is valid only when no attempt has been made by the party concerned to bring the case to the attention of the authorities, and also that lack of action is not due to fear of inviting adverse or hostile reaction from any quarters. Any attempt made to report the issue to the authorities will disrupt taqadum and that will then count as a new starting point. ${ }^{59}$

Taqadum evidently relates to post-conflict justice, as large scale conflicts that engulf countries such as Afghanistan, Iraq, Somalia and Libya etc., are most likely long term. Passage of time, lack of prosecution and court judgment could be, or alleged to be, due to uncertainties of the justice system in times of open conflict, which could well be a valid excuse. Lapse of time is, in any case, likely to affect aspects of evidence and proof, and strengthen to that extent the likelihood of reconciliation and compromise. It would be difficult, however, to speak of reconciliation if the guilty party/parties refuse to admit wrongdoing and refuse to seek forgiveness. 


\section{Conclusion}

The twin objectives of this article had been to review the Islamic law provisions on amnesty and pardon as are expounded by its leading schools and scholars, and then also to explore the prospects of needed reform of some of its relevant provisions. This approach coincides with the binary concern of Islamic law for continuity and change, and Islamic jurisprudence provides a number of principles and formulas to facilitate them.

The Shariah is often characterised as a 'diversity within unity.' Diversity is due to a degree of flexibility and openness in the language of the text, especially of the Qur'an, to fresh interpretation and ijtihad. The unifying dimension of Shariah is manifested in its recognition of the overriding authority of tawhid (Divine Oneness, the Oneness of Being), and the principle of consensus (ijma ') ${ }^{60}$ These and certain other principles of Islamic jurisprudence are accountable for the continued relevance of Shariah to the applied laws of Muslim countries to this day. Yet if it were to retain its vitality and relevance, the Shariah needs to be read side by side with the changing facets of social reality and the living conditions of people.

It is important to know the juristic details of figh and how Muslim scholars have tried to contextualise the source guidelines of Islam with their own conditions and realties. Hudud and qisas laws still constitute the mainstay of Islamic criminal law, and can hardly be dismissed altogether in the name of modernity and change, or of amnesty and reconciliation. Yet the realities of criminal justice system and that of the nation state that now prevail are indicative of discontinuity, in some respects at least, with the fiqh details of hudud and qisas - as I earlier explained. The prevalence of taqlid for many centuries and then of colonial rule disrupted the continuity of Shariah, scriptural interpretation and ijtihad. We are now left with a larger challenge in Afghanistan, Iraq and Libya as also in many other Muslim jurisdictions, of realising the right blend of statutory law of a western type and those of Islamic principles. But since realisation of human welfare, peace and normal order in society constitute the cardinal objectives (maqasid) of Shariah, all bona fide efforts that do not compromise the integrity of truth and justice and seek to put an end to conflict command Shariah validity. This presentation has addressed aspects of Islamic justice in regard to hudud and qisas and the place of amnesty and forgiveness therein, but realise in the meantime that legalities may need to be contextualised, even superseded, if one's bona fide efforts are likely to realise the higher objectives of Islam to end conflict, save people's lives, and restore peace.

I may end this presentation with a proposal for the formation of a truth and reconciliation commission (TRC) for Afghanistan, a country I have known best, and any other country that may find this proposal relevant and useful for 
their purposes. The TRC should include non-partisan Afghans that comprise of Shariah and modern law experts, prominent academicians and peace negotiators from within Afghanistan and outside, current or former senior judges, and a representatives each from the parties to conflict with clean records, as well representatives from the UN and Organisation of Islamic Cooperation (OIC). A set of guidelines and procedures should be drafted and approved by parliament and the head of state. There should be timelines and carefully regulated phases of progress for purposes of evaluation and measurement. The TRC may sit as an associate body of the Independent Human Rights Commission of Afghanistan, but should otherwise be totally independent. It should present its findings to the Supreme Court either to confirm and return the file to the TRC, or in the case of serious objections, to specify them and return it file to the TRC preferably within a month. The Supreme Court does not adjudicate otherwise, and the TRC itself decides on further action that leads to desired results - again within a specified period of time.

\section{Notes}

* Mohammad Hashim Kamali, Founding CEO of IAIS Malaysia, graduated from Kabul University, and took his $\mathrm{PhD}$ in Islamic and Middle Eastern Law at the University of London in 1969. Professor Dr M. H. Kamali served as Professor of Islamic Law and Jurisprudence at the International Islamic University Malaysia (IIUM, 19852007), then Dean of the International Institute of Islamic Thought and Civilization (ISTAC). He also held Visiting Professorships at McGill University's Institute of Islamic Studies; Capital University, Ohio; and the Wissenschaftskolleg, Berlin. A member of the Constitution Review Commission of Afghanistan (2003), he has provided expert legal consultation to the new constitutions of Iraq, the Maldives and Somalia. Eminent authority on Islamic legal studies, he has published over 170 academic articles and 35 texts, including standard textbooks at universities worldwide. He can be contacted at ceo@iais.org.my.

** No distinction between "amnesty" and "pardon" is made in their meanings in this article since in Shariah law this distinction is also not made. Western jurisprudence does, however, reserves pardon for removal of punishment after adjudication whereas amnesty is not limited by this framework.

1. Wizarat al-Awqaf wa'l-Shu'un al-Islamiyyah, al-Mawsu'ah al-Fiqhiyyah, Kuwait, 1994/1414, Vol. 30, p. 168.

2. Ibid., pp. $20 \& 167$.

3. Wizarat al-Awqaf, al-Mawsu'ah, Vol.30, p. 167; Abu Bakar Jabir al-Jaza'iri, Aysar al-Tafasir li-Kalam al-'Aliyy al-Kabir, Jeddah: Rasim li'l-Di'ayah wa'lI'lan, 1987/1407, Vol. 1, p. 316.

4. Muslim b. Hajjaj al-Nishapuri, Mukhtasar Sahih Muslim, ed. Muhammad Nasir al-Din al-Albani, $2^{\text {nd }}$ ed., Beirut: Dar al-Maktab al-Islami, 1984/1404, p. 475, hadith no. 1790.

5. Cf., Hanan 'Atiyyah al-Juhni, “Dawr al-Walidayn fi Tanshi'at al-Abna' 'ala 
Khuluq al-'Afwa," Majallah Jami'ah Umm al-Qura li'l- 'Ulum al-Tarbawiyyah wa'l-Nafsiyyah (Saudi Arabia), Vol. 2, no. 2 (July 2010/Rajab 1431), 279.

6. Hadith on the authority of Jabir bin 'Abd Allah recorded in al-Bukhari, Sahih al-Bukhari, Cairo: Dar al-Hadith, 2004, 4 Vols., Vol. 2, hadith no. 2617 at p. 219.

7. Muhammad bin Isma'il al-Bukhari, Sahih al-Bukhari, Vol. 2, hadith no. 2910 at p. 305 .

8. Ibid., Vol. 4, hadith no. 6929 at p. 314.

9. See for more reports Hanan 'Atiyyah al-Juhni, "Dawr al-Walidayn," pp. 260-61.

10. Shuf' $a$ is the right of a neighbour giving him priority over other people to purchase an adjacent property when it is offered for sale.

11. Cf., 'Abd al-Qadir 'Awdah, al-Tashri' al-Jina'i al-Islami Muqarinan b'l-Qanun al-Wad'I, 2 Vols. 13 ${ }^{\text {th }}$ edn., Beirut: Muassasah al-Risalah, 1994/1415, Vol.1, p. 774.

12. See for details, Muhammad Abu Zahrah, Al-Jarimah wa'l- 'Uqubah fi'l-Fiqh alIslami: al-'Uqubah, Cairo: Dar al-Fikr al-'Arabi, 2006, pp. 226-227. See also 'Awdah, al-Tashri' al-Jina'i al-Islami, Vol. 1, p. 353.

13. Cf., 'Awdah, al-Tashri' al-Jina'i al-Islami, Vol. 1, p. 354.

14. Ibid., 354-55.

15. Ibid.

16. Cf., 'Awdah, al-Tashri', Vol. 1, 355.

17. Abu Zahrah, al-'Uqubah, p.231.

18. Abu Zahrah, al-'Uqubah, p. 231. Al-Mawardi and al-Farra's views also appear in Wizarat al-Awqaf, Mawsu'ah Fiqhiyyah, Vol. 30, pp. 185-186.

19. Abu Zahra, al-'Uqubah, p. 227. See also Kamali, Punishment in Islamic Law, pp. $56 \& 59$.

20. Abu 'Abd Allah al-Khatib al-Tabrizi, Mishkat al-Masabih, ed. Muhammad Nasir al-Din al-Albani, $2^{\text {nd }}$ edn. Beirut: al-Maktab al-Islami, 1399/1979, Vol. II, p. 1061, hadith no. 3570. See also Abu Yusuf Ya'qub b. Ibrahim, Kitab al-Kharaj, $5^{\text {th }}$ ed. Cairo, al-Matba'ah al-Salafiyyah, 1396/1976, p. 164. Mishkat al-Masabih is a select collection of hadith from the authoritative six collections, known as alsihah al-sittah. See also on the expression hudud, Kamali, Punishment in Islamic Law, 45f.

21. See for details Mohammad Hashim Kamali, Punishment in Islamic Law: an Enquiry into the Hudud Bill of Kelantan, Kuala Lumpur: Institut Kajiian Dasar, 1994; reprint by Ilmiah Publishers of Kuala Lumpur, 2000, especially Section iii entitled "An analysis of hadd in the Qur'an, Sunnah and fiqh" (pp. 45-85) and IV entitled " the Philosophy of hudud" (pp. 85-90).

22. Abu Yusuf Ya'qub Ibrahim, Kitab al-Kharaj, $5^{\text {th }}$ edn., Cairo: al-Matba'ah alSalafiyyah, 1396, p. 163.

23. Abu Zahrah, al-Jarimah, p. 227. See also for a review of the scholastic positions, Mawsu'ah Fiqhiyyah, Vol. 30, p. 184f.

24. 'Abd Allah Muhammad b. Yaziz al-Qazwini, better known as Ibn Majah, Sunan Ibn Majah, 2 ${ }^{\text {nd }}$ ed., Beirut: Daral-Kutub al-'Ilmiyyah, 2004/1425, p. 689, hadith no. 4250 .

25. Ibid., p.184. For a more detailed discussion of hudud and reform proposals on them see M H Kamali, Punishment in Islamic Law.

26. This is because hadd is by definition a crime for which the Qur'an or hadith 
specifically prescribes a punishment. The Qur'an is silent on this but an ahad (solitary) hadith makes apostasy liable to capital punishment. The majority position of the legal schools on this issue is also not devoid of an element of uncertainty on the purport of the specific wordings of the relevant hadith. See for details Mohammad Hashim Kamali, Freedom of Expression in Islam, Cambridge: Islamic Texts Society, 1997, pp. 212-250.

27. Abu Zahrah, al-'Uqubah, p. 233.

28. The maqasid al-shari 'ah includes the safety and protection of human life and intellect, a normal order in society, protection of religion, private property and family. For details on maqasid see Kamali, Shari 'ah Law, chapter 6, pp. 123-141 in the next note.

29. For details on Siyasah see Mohammad Hashim Kamali, Shari 'ah Law: an Introduction, Oxford: Oneworld Publications, 2008, ch. 11: "Beyond the Shari'ah: an Analysis of Shari'ah-Oriented Policy (Siyasah Shar'iyyah)," 225 246.

30. Chawkat Moucarry, The Search for Forgiveness: Pardon and Punishment in Islam and Christianity, Leicester (UK): Inter-Varsity Press, 2004, p.282.

31. The precise number of hudud offences varies as to whether one includes apostasy (iddah) and wine drinking (shrub) in them or not, but the rest of the hudud consist of theft (sariqah), adultery (zina), slanderous accusation (qadhf) and highway robbery/terrorism (hirabah).

32. Cf., 'Awdah, al-Tashri' al-Jina'i, Vol.1, pp. 777 \& 559-560.

33. See further details on the limitations of ta'zir Mohammad Hashim Kamali, The Right to Life, Security, Privacy and Ownership in Islam, Cambridge: Islamic Texts Society, 2008, pp. 96-97. See for details on Siyasah Shar 'iyyah, Mohammad Hashim Kamali, Freedom, Equality and Justice in Islam, Cambridge: Islamic Text Society, 2000, pp. 143-149, and on ta'zir as an aspect of siyasah, p. 149.

34. Cf., Kamali, The Right to Life, pp. 17-19; see also Cherif Bassiouni, edr., The Islamic Criminal Justice System, London \& New York: Oceana Publications, 1982, p. 209.

35. The quantum of diyyah is determined at 100 camels or its monetary equivalent.

36. See for details Mohammad Hashim Kamali, The Right to Life, p. $12 \mathrm{f}$.

37. Cf., Abu Zahrah, al- 'Uqubah, pp. 483 \& 485.

38. See for details Wizarat al-Awqaf, Mawsu'ah Fiqhiyyah, Vol. 30, p. $174 \mathrm{f}$.

39. See for details Mohammad Hashim Kamali, Principles of Islamic Jurisprudence, 2003 edn., pp. 364-65.

40. See for details, 'Awdah, Al-Tashri' al-Jina'i, Vol.1, p. 175f.

41. Kaffarah lit. means a concealer in that it can conceal and relieves the person from other sins.

42. This hadith is recorded in Abu Dawood, Mukhtasar Sunan Abi Dawood, ed. Mustafa Dib al-Bugha, Damascus: Dar al-'Ulum al-Insaniyyah, 1995/1416, hadith no. 4497 at p. 643. Abu Dawud has remained silent about (evaluating it) this hadith, whereas al-Shawkani who recorded it in his Nayl al-Awtar went on to say that there is no problem in its chain of transmitters (isnad). See Wizarat al-Awqaf, Al-Mawsu'ah al-Fiqhiyyah, Vol. 30, p. 174.

43. Case cited in Abu Zahrah, al-'Uqubah, p. 483. This hadith is also recorded by al-Bukhari, The Translation of the Meaning of Sahih al-Bukhari, tr. Muhammad 
Muhsin Khan, $4^{\text {th }}$ revised ed. Lahore: Kazi Publications, 1979, Vol. IX, hadith no. 23.

44. Mawsu'ah Fiqhiyyah, Ibid, Vol. 30, at 174.

45. Tabrizi, Mishkat al-Masabih, Vol. II, hadith no. 3477. See for further details, Kamali, The Right to Life, p. 18f.

46. Jamal al-Din Al-Zaylai, Bahr al-Ra'iq, Vol. 8, p. 300 as quoted in 'Awdah, alTashri', Vol. 1, p. 776.

47. Hadith narrated by 'Amr ibn Shu'ayb from his father, from his grandfather, from the Prophet. See Ibn Muwaffaq al-Din Qudamah, al-Mughni, Cairo: Mutba'ah al-Manar, 1367H, Vol.9, p. 477; 'Awdah, al-Tashri'al-Jina'i, Vol. 1, p, 774.

48. Cf., 'Awdah, al-Tashri' al-Jina'i, Vol. 1, p. 774.

49. Cf., Abu Zahrah, al- 'Uqubah, p. 492.

50. 'Ala al-Din al-Kasani, Bada 'i'al-Shara 'i'fi Tartib al-Shara'i', Cairo: Matba'ah al-Istiqamah, 1956, Vol. 10, p. 4655. See also Mawsu'ah Fiqhiyyah, Vol. 30, p. 183.

51. Cf., Abu Zahrah, al-'Uqubah, p. 486.

52. Ibid, p. 487. See also Mawsu'ah Fiqhiyyah, Vol. 30, p. 177.

53. See for details, Mawsu'ah Fiqhiyyah, Vol. 30. pp. 177-182.

54. 'Awdah, al-Tashri' al-Jina'i, p. 781.

55. See for details Subhi Mahmassani, al-Nazariyyah al- 'Ammah li'l-Mojibat wa'l'Uqud, $3^{\text {rd }}$ edn., Beirut: Dar al-'Ilm li'l-Malayin, 1983, p. 568.

56. Muhammad Amin Ibn 'Abidin, Hashiyah Radd al-Mukhtar ila Durr al-Mukhtar, also known as Hashiyah Ibn 'Abidin, Cairo: Dar al-Fikr, 1399/1979, Vol. 3, p. 218.

57. 'Awdah, al-Tashri'al-Jina'i, p. 781.

58. Mahmassani, Al-Nazariyyah al-'Ammah, p. 570.

59. See the Ottoman Mejelle, Articles 1661, 1662, and 1675 on the relevance of taqadum to property claims over usurpation and unlawful possession, also discussed in Mahmassani, Nazariyyah, p. $567 \mathrm{f}$.

60. See for details on Tawhid, Kamali, Shari'ah Law: An Introduction, pp. 17-19. There is also a chapter on ijma' in Kamali, Principles of Islamic Jurisprudence, pp. 228-264. 